\title{
Combined sodium hydroxide and ammonium hydroxide pretreatment of post-biogas digestion dairy manure fiber for cost effective cellulosic bioethanol production
}

Sasikumar Elumalai ${ }^{1}$, Aicardo Roa- Espinosa ${ }^{1,2}$, John L Markley ${ }^{3}$ and Troy M Runge ${ }^{1 *}$

\begin{abstract}
Background: The current higher manufacturing cost of biofuels production from lignocellulosics hinders the commercial process development. Although many approaches for reducing the manufacturing cost of cellulosic biofuels may be considered, the use of less expensive feedstocks may represent the largest impact. In the present study, we investigated the use of a low cost feedstock: post-biogas digestion dairy manure fiber. We used an innovative pretreatment procedure that combines dilute sodium hydroxide with supplementary aqueous ammonia, with the goal of releasing fermentable sugar for ethanol fermentation.
\end{abstract}

Results: Post-biogas digestion manure fiber were found to contain $41.1 \%$ total carbohydrates, $29.4 \%$ lignin, $13.7 \%$ ash, and $11.7 \%$ extractives on dry basis. Chemical treatment were applied using varying amounts of $\mathrm{NaOH}$ and $\mathrm{NH}_{3}(2-10 \%$ loadings of each alkali on dry solids) at mild conditions of $100^{\circ} \mathrm{C}$ for $5 \mathrm{~min}$, which led to a reduction in lignin of $16-40 \%$. Increasing treatment severity conditions to $121^{\circ} \mathrm{C}$ for 60 min improved delignification to $17-67 \%$, but also solubilized significant amounts of the carbohydrates. A modified severity parameter model was used to determine the delignification efficiency of manure fiber during alkaline pretreatment. The linear model well predicted the experimental values of fiber delignification for all pretreatment methods $\left(R^{2}>0.94\right)$. Enzymatic digestion of the treated fibers attained $15-50 \%$ saccharification for the low severity treatment, whereas the high severity treatment achieved up to 2 -fold higher saccharification. Pretreatment with $\mathrm{NaOH}$ alone at a variety of concentrations and temperatures provide low delignification levels of only $5-21 \%$ and low saccharification yields of $3-8 \%$, whereas pretreatment with the combination of $\mathrm{NaOH}$ and $\mathrm{NH}_{3}$ improved delignification levels and saccharification yields 2-3.5 higher than pretreatment with $\mathrm{NH}_{3}$ alone. Additionally, the combined $\mathrm{NaOH}$ and $\mathrm{NH}_{3}$ pretreatment led to noticeable changes in fiber morphology as determined by SEM and $\mathrm{Crl}$ measurements.

Conclusions: We show that combined alkaline treatment by $\mathrm{NaOH}$ and $\mathrm{NH}_{3}$ improves the delignification and enzymatic digestibility of anaerobically digested manure fibers. Although pretreatment leads to acceptable saccharification for this low-cost feedstock, the high chemical consumption costs of the process likely will require recovery and reuse of the treatment chemicals, prior to this process being economically feasibility.

Keywords: Biogas, Digestion, Manure fiber, Sodium hydroxide, Ammonium hydroxide, Alkaline pretreatment, Enzyme saccharification

\footnotetext{
* Correspondence: trunge@wisc.edu

'Department of Biological Systems Engineering, 460 Henry Mall, University of

Wisconsin-Madison, Madison, WI 53706, USA

Full list of author information is available at the end of the article
}

\section{() Chemistry Central}

(c) 2014 Elumalai et al.; licensee Chemistry Central Ltd. This is an Open Access article distributed under the terms of the Creative Commons Attribution License (http://creativecommons.org/licenses/by/4.0), which permits unrestricted use, distribution, and reproduction in any medium, provided the original work is properly credited. The Creative Commons Public Domain Dedication waiver (http://creativecommons.org/publicdomain/zero/1.0/) applies to the data made available in this article, unless otherwise stated. 


\section{Background}

Global consumption of non-renewable fossil fuels in the transportation sector has increased vigorously during the last three decades with simultaneous increment in price of fuels $[1,2]$. For economic and environmental reasons, it is critical to find replacements for fossil fuels. Renewable, second-generation cellulosic biofuels offer the potential to improve energy security and reduce the deleterious environmental impact of first generation biofuels [3-6]. However, challenges remain in converting lignocellulosic biomass into sustainable biofuels in a cost- and energyeffective manner at large-scale [7-9]. The most commonly investigated lignocellulosic feedstocks for potential ethanol production are agricultural (crop residues) and forestry wastes (mill residues). Both of these feedstocks are natural composites consisting of three main biopolymers; cellulose, hemicellulose, and lignin [10-15]. Several studies [16-20] have demonstrated the potential of manure fibers (either pre- or post-biogas digestion) as a lignocellulose feedstock for the production of biofuels and value-added chemicals. The composition of manure fibers depends on the animal feed and the conditions of anaerobic digestion if carried out. The dry fibers typically have a high content of both carbohydrate $(40-43 \%)$ and lignin $(20-25 \%)$. Manure fiber is plentiful. In average, dairy cattle produce about 12.0 gal of manure per $1,000 \mathrm{lb}$ live weight per day with $14.4 \mathrm{lb}$ total solids. For example, the United States alone produces 110 million tonnes (d.b.) of manure annually. This manure supply could generate about 60 tonnes of biogas along with 60 million dry tonnes of undigested fibers that could produce an additional 7.6 billion liters (1.7 billion gallons) of ethanol $[21,22]$. Traditionally, most manure has been spread on fields, but digestion for biogas production is becoming more common in almost all countries [23-26]. The undigested manure byproduct of biogas production primarily is applied as a nutrient to farmland, but a small part is utilized for animal bedding [27], manure composts for organic fertilizer [28-30], and even the manufacture of particleboard [31]. Because manure fibers are known to be highly recalcitrant to enzymatic digestion, efforts on the conversion of manure fibers into biofuels have been limited [20]. Anaerobic digestion of manure for the production of biogas consumes hemicellulose and nearly all-available soluble sugars and leave cellulose and lignin untouched [20,32]. In addition, undesired components associated with nitrogenous extractives and ash increase the cost of biofuels production [33-35]. The recalcitrant nature of biomass is attributed to tight lignin wrapping, which prevents the accessibility of the biomass carbohydrate fractions (cellulose/hemicellulose) to enzymes, hemicellulose sheathing, cellulose crystallinity, and degree of polymerization [9,36]. Lignin not only hinders enzyme accessibility to cellulose but also provides the nonproductive and/or irreversible binding of enzymes [37]. Therefore, a pretreatment step mechanical and/or chemical is necessary to modify the lignocellulose complex matrix structure in such a way as to disrupt lignin, dissolve hemicelluloses, and break down the cellulose crystallinity in order to enhance substrate accessibility to enzymes and in turn, release more fermentable sugars [38,39].

In general, nitrogenous matter in anaerobically digested fiber increases its alkalinity (to $\mathrm{pH} 8.5$ - 9.0). Therefore, alkaline pretreatments are expected to require less chemical than acidic pretreatments [20]. Alkaline biomass pretreatment methods using either sodium hydroxide [40,41] or aqueous ammonia [42] have been studied in recent years and shown to have high efficiency and low cost $[14,38]$. Sodium hydroxide treatment effectively depolymerizes and removes the most labile biomass components, such as hemicelluloses and lignin, causes swelling that increases enzyme accessible surface area (for solvation and saponification reactions) and reduces the degree of polymerization and crystallinity of cellulose [40]. Aqueous ammonia reacts selectively with lignin by cleaving $\mathrm{C}-\mathrm{O}-\mathrm{C}$ bonds in lignin and ether and ester bonds in lignincarbohydrate complexes, but carbohydrate removal and/ or degradation is limited. In addition, these treatments cause significant morphological changes in the lignocellulose to improve enzyme accessibility $[43,44]$. However, aqueous ammonia may not be effective for the pretreatment of substrates having relatively higher lignin (wood feedstocks) [38]. According to reviews, maximum delignification ( $64 \%)$ with enzymatic saccharification ( 65\%) could be achieved for anaerobically digested manure fiber by using dil. $\mathrm{NaOH}$ under elevated temperature $[20,45]$. Also, the addition of supplementary reagents to the alkali pretreatment chemicals, such as oxidizing agents [46] or lime [47], has been shown to further improve delignification and subsequent enzymatic digestion of lignocellulose substrates [48]. As pretreatment protocols for post-biogas digestion (PBD) manure fiber, which contain high residual lignin, aimed at improving enzymatic digestion for ethanol fermentation, we explored the use of dilute sodium hydroxide and/or aqueous ammonia. The addition of $\mathrm{NaOH}$ to $\mathrm{NH}_{4} \mathrm{OH}$ shifts the equilibrium to form gaseous $\mathrm{NH}_{3}$, a reversible reaction that could be used to facilitate its recovery and reuse so as to improve the cost-effectiveness of this process (Figure 1) [49]. The fibers were then enzymatically saccharified to convert glucan to glucose to determine the effectiveness of the pretreatments. The pretreated fibers were also examined by scanning electron microscopy and $\mathrm{x}$-ray diffraction measurements to determine cellulose crystallinity.

\section{Results and discussion}

\section{Characterization of post-biogas digestion manure fiber}

As determined by mechanical sieve analysis, the postbiogas digestion (PBD) manure fiber that had undergone alkaline pretreatment displayed a fiber size range from 


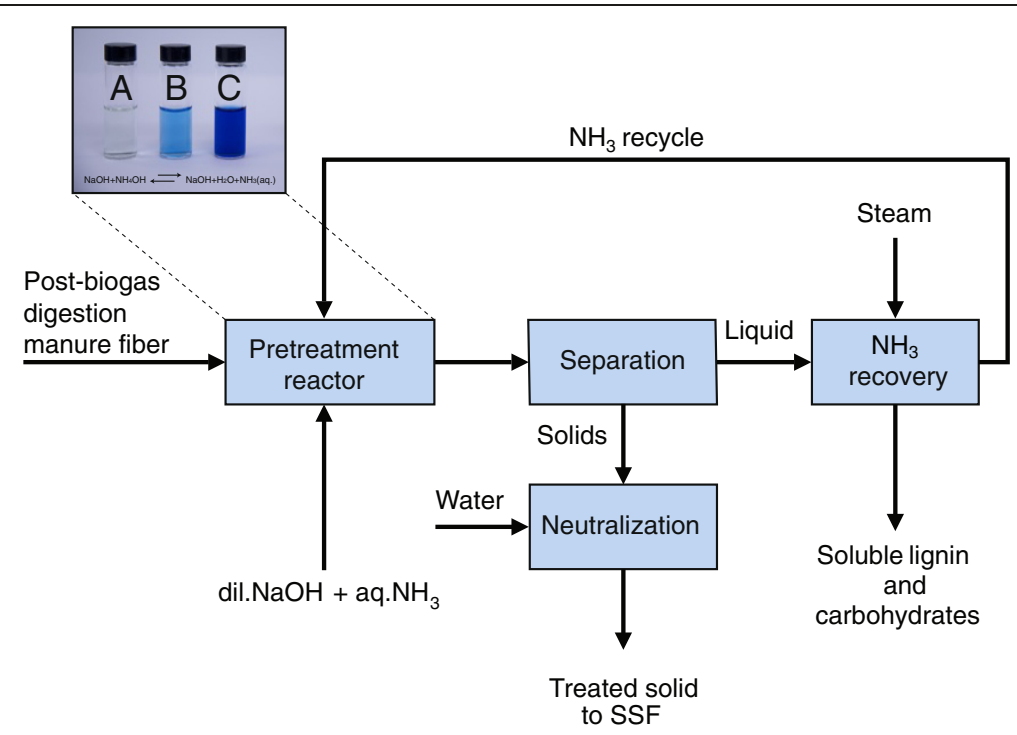

Figure 1 Schematic representation of the pretreatment of post-biogas digestion manure fibers for cellulosic bioethanol production by $\mathrm{NaOH}$ and $\mathrm{NH}_{4} \mathrm{OH}$. The inset shows (A) reference blank, (B) $0.25 \%$ conc. $\mathrm{NH}_{4} \mathrm{OH}(5 \mathrm{~mL})$, and (C) $0.25 \%$ conc. $\mathrm{NaOH}$ (2.5 mL) plus $0.25 \% \mathrm{conc}$. $\mathrm{NH}_{4} \mathrm{OH}(2.5 \mathrm{~mL})$ [49].

2.4 $\mathrm{mm}$ to $<75 \mu \mathrm{m}$ with a calculated number average diameter $\left(\mathrm{D}_{\mathrm{N}}\right)$ of $0.041 \mathrm{~mm}$ and volume surface mean diameter $\left(D_{S}\right)$ of $0.415 \mathrm{~mm}$ [50]. Particles smaller than 18 -mesh $(1.0 \mathrm{~mm})$ accounted for $93 \%$ of PDB fibers (dry basis), as compared to about $73 \%$ of pre-biogas digestion manure fibers. The effects anaerobic bacterial digestion lead to smaller particle sizes [20]. In general, particle size plays a significant role in the effectiveness of the pretreatment and fermentation steps [51,52], with smaller fiber size being advantageous for bioconversion. The PBD manure fiber contained $41.1 \%$ carbohydrate by weight, of which $23.6 \%$ was glucose and $17.5 \%$ other sugars (xylose, galactose, arabinose and mannose) (Table 1). The carbohydrate content of PBD manure fiber is $25-28 \%$ lower than those of other commonly used substrates for cellulosic ethanol production (corn stover, switch grass, sugarcane bagasse, and wheat straw) [15]. More accessible carbohydrate sugars are digested in the animal and during anaerobic digestion. The low carbohydrate content of PBD manure fibers leads to carbohydrate/lignin ratios $60-65 \%$ lower than in other agricultural biomass. PBD manure fibers contained $27.6 \%$ acid insoluble lignin (ash free and Klason) and $1.8 \%$ acid soluble lignin. Analysis of lignin monomers yielded 19:71:10 syringyl (S):guaiacyl (G):p-hydroxyphenyl $(\mathrm{H})$ on dry basis, ratios consistent with corn stover lignin $[42,53]$. Fiber ash, a non-reactive and undesired component of manure fiber for biofuels production, which negatively affects ethanol yields particularly from thermochemical ethanol production [54], accounted for $13.7 \%$ (dry basis). It has been reported that manure fiber also contains $\sim 12 \%$ solvent extractives, composed mainly of nitrogenous materials, nonstructural sugars, inorganics, waxes, oils, and other compounds [55]. The predominant component, nitrogenous material, comes from indigestible forage proteins and ammonia and other nitrogen compounds in urine and manure. This nitrogen could be a potential nutrient source for microbial growth in ethanol fermentation $[17,35]$; however, biomass extractives interfere with analytical measurements [56,57] and thus were not considered in our study.

\section{Alkaline pretreatment of PBD manure fiber}

We investigated the pretreatment of PBD manure fiber by dilute sodium hydroxide and ammonium hydroxide (SHAH). We studied the effects of different pretreatment parameters, including alkali loading, temperature, and residence time, on the recovery and subsequent enzymatic digestion of PBD manure fiber (Table 2). We used low-severity protocols to evaluate pretreatment under conditions that minimized the cost of chemicals and the energy needed to heat the samples: $100^{\circ} \mathrm{C}$ for $5 \mathrm{~min}$ at concentrations of $2-10 \%$ (by dry fiber weight) of $\mathrm{NaOH}$ and $\mathrm{NH}_{3}[41,58]$. These pretreatment protocols led to substantial decreases in fiber residual lignin (16 - 40\% delignification) and improved carbohydrate recovery (80-67\%) and higher carbohydrate concentration (2-10\%). The pretreatment yields were calculated based on a comparison between the weight of contents present in the sample before (initial) pretreatment and the weight of contents present in the solids remaining after pretreatment. These low severity pretreatment conditions achieved higher fiber delignification than higher severity conditions $[20,47,59]$. We also investigated the effects of higher 
Table 1 Compositional analyses result of post-biogas digestion manure fiber (anaerobically bacterial digested)

\begin{tabular}{|c|c|}
\hline Component & $\begin{array}{l}{ }^{a} \text { Post-biogas digestion } \\
\text { manure fiber, dry basis }\end{array}$ \\
\hline \multicolumn{2}{|l|}{ Carbohydrate } \\
\hline Glucose & $23.6 \pm 0.3 \%$ \\
\hline $\begin{array}{l}\text { Xylose, Galactose, Arabinose, } \\
\text { and Mannose }\end{array}$ & $17.5 \pm 0.3 \%$ \\
\hline \multicolumn{2}{|l|}{ Lignin } \\
\hline Acid insoluble lignin & $27.6 \pm 0.1 \%$ \\
\hline Acid soluble lignin & $1.8 \pm 0.0 \%$ \\
\hline \multicolumn{2}{|l|}{ Lignin monomer } \\
\hline${ }^{b} \mathrm{~S} / \mathrm{G}$ ratio & 0.3 \\
\hline $\mathrm{S} / \mathrm{H}$ ratio & 1.9 \\
\hline H/G ratio & 0.1 \\
\hline Uronic acid & $2.6 \pm 0.1 \%$ \\
\hline Ash & $13.7 \pm 0.1 \%$ \\
\hline Extractives & $11.7 \pm 0.1 \%$ \\
\hline \multicolumn{2}{|l|}{ Fiber elements } \\
\hline C & $39.1 \pm 0.4 \%$ \\
\hline N & $3.3 \pm 0.2 \%$ \\
\hline$P$ & $1.1 \pm 0.0 \%$ \\
\hline K & $1.4 \pm 0.0 \%$ \\
\hline $\mathrm{Ca}$ & $4.8 \pm 0.6 \%$ \\
\hline $\mathrm{Mg}$ & $0.8 \pm 0.1 \%$ \\
\hline S & $1.0 \pm 0.0 \%$ \\
\hline $\mathrm{Cl}$ & $0.4 \pm 0.1 \%$ \\
\hline $\mathrm{Fe}$ & $0.3 \pm 0.1 \%$ \\
\hline $\mathrm{Zn}$ & $0.1 \pm 0.0 \%$ \\
\hline
\end{tabular}

${ }^{a}$ Data are average of two replicates. Numbers with \pm values represent standard errors; ${ }^{b}$ Syringyl (S), guaiacyl (G), and $p$-hydroxyphenyl (H) lignin.

temperature $\left(120^{\circ} \mathrm{C}\right.$ at $\left.15 \mathrm{psi}\right)$ and longer residence time (60 min) at different concentrations of $\mathrm{NaOH}$ and ammonia (Table 2). The more stringent conditions led to modest increases in total sugars and reductions in total lignin. The results were consistent with the literature [20] and observed approximately 2-3-fold increase on pretreatment recovery.

We compared the effects of SHAH pretreatment protocols with those using $\mathrm{NaOH}$ and aqueous $\mathrm{NH}_{3}$ singly under conditions of $121^{\circ} \mathrm{C}$ at 15 psi and $60 \mathrm{~min}$ (Table 2). In terms of solids recovered, total sugars, and total lignin, treatment with $\mathrm{NaOH}$ alone was equivalent to SHAH pretreatment; for both, increased alkali loading led to lower solids recovery, higher total sugars, and lower total lignin. Treatment with aqueous $\mathrm{NH}_{3}$ alone led to higher solids recovery, slightly lower total sugars and higher total lignin. Increasing concentrations of aqueous ammonia had little effect on glucose, total sugars, or total lignin. A linear model relating modified severity parameter that combines the effects of temperature, time, and alkali concentration to the percentage removal of lignin was used for the determination of fiber delignification during alkaline pretreatments. The model was developed by plotting $\log \left(M_{0}\right)$ vs percent delignification, as given in Figure 2. The modified severity parameter model was validated by plotting the experimental vs model predicted values of fiber delignification (Additional file 1: Figure S1) and observed $\mathrm{R}^{2}>0.94$ for all pretreatment methods; indicating good predictive ability of the model.

\section{Effects of alkaline pretreatment of PBD manure fiber on} subsequent enzyme saccharification

We carried out enzymatic digestion of pretreated PDB manure fiber to determine the release of fermentable sugar for ethanol fermentation (Figure 3). The typical enzymatic hydrolysis profile showed rapid saccharification over $6 \mathrm{~h}$ followed by leveling off thereafter (Figure 3A). Enzymatic hydrolysis results of $\mathrm{SHAH}$ pretreatment at $100^{\circ} \mathrm{C}$ (Figure 3B) showed saccharification yields of $15-49 \%$ with $18-55 \%$ glucose conversion after $24 \mathrm{~h}$ with a corresponding increase in concentration of $5-3 \%$ points difference between each concentration increment. Approximately 1.5 2.0-fold increase in saccharification yield was achieved with $121^{\circ} \mathrm{C}$ at $15 \mathrm{psi}$ and $60 \mathrm{~min}$ pretreatment (Figure 3B), indicating that removal of residual lignin (relatively 8-66\% higher delignification) and other substrate features had significant impact on the improved enzyme accessibility for fiber digestion [60]. SHAH pretreatment achieved 3-8\% and 1.5-2.5-fold higher saccharification than separate $\mathrm{NaOH}$ and $\mathrm{NH}_{3}$ pretreatments, respectively (Figure $3 \mathrm{C}$ ). Also, it was approximately 3-fold higher saccharification than Teater et al. [20].

\section{Effects of pretreatment of PBD manure fiber on surface structure and cellulose crystallinity}

We used scanning electron microscopy (SEM) to determine the effects of pretreatment on the surface features of the fibers. PBD manure fibers that were not pretreated (Figure 4A) or pretreatment with $\mathrm{NaOH}$ alone (Figure 4B) or aqueous NH3 alone (Figure 4C) exhibited rigid and highly ordered surface structure. By contrast the SEM image of fibers that underwent SHAH pretreatment exhibited sponge-like structures and an apparent increase in fiber porosity (Figure 4D) [39,40].

We used X-ray powder diffraction pattern to determine the effects of pretreatment on cellulose crystallinity. The results (shown in Figure 5A) showed that the three treatment protocols at $121^{\circ} \mathrm{C}$ and 15 psi reduced crystallinity in the order: $10 \% \mathrm{NH}_{3}<10 \% \mathrm{NaOH}<10 \%$ $\mathrm{NaOH}+\mathrm{NH}_{3}$. SHAH pretreatment greatly alters the crystalline structure by the competitive reaction of both alkalis resulting in the formation of different allomorphs that have different unit cell dimensions, chain packaging, 
Table 2 Pretreatment recovery and solid residues composition of post-biogas digestion manure fiber after treatment using $\mathrm{NaOH}$ and $\mathrm{NH}_{3}$ at different conditions

\begin{tabular}{|c|c|c|c|c|c|c|c|c|}
\hline \multicolumn{2}{|c|}{ Alkali loading\%, gm/gm dry solids } & \multirow{2}{*}{$\begin{array}{c}\text { Temperature } \\
\left({ }^{\circ} \mathrm{C}\right)\end{array}$} & \multirow{2}{*}{$\begin{array}{l}\text { Residence } \\
\text { time (min) }\end{array}$} & \multirow{2}{*}{$\begin{array}{c}{ }^{a} \text { Modified } \\
\text { CS factor, } \\
\log M_{o}\end{array}$} & \multirow{2}{*}{$\begin{array}{l}\text { Solids } \\
\text { recovery\% }\end{array}$} & \multicolumn{3}{|c|}{ Residue composition\%, dry basis } \\
\hline Dilute $\mathrm{NaOH}$ & Aqueous $\mathrm{NH}_{3}$ & & & & & Glucose & ${ }^{b}$ Total sugars & $\begin{array}{l}{ }^{c} \text { Total lignin } \\
\text { (AIL + ASL) }\end{array}$ \\
\hline 2.0 & 2.0 & 100 & 5 & $0.09(n=0.89)$ & $80.6 \pm 0.1$ & $24.2 \pm 0.2$ & $41.1 \pm 0.6$ & $31.1 \pm 0.1$ \\
\hline 4.0 & 4.0 & 100 & 5 & 0.35 & $76.6 \pm 0.0$ & $24.7 \pm 0.4$ & $42.0 \pm 0.4$ & $31.0 \pm 0.4$ \\
\hline 6.0 & 6.0 & 100 & 5 & 0.51 & $72.0 \pm 0.5$ & $25.0 \pm 0.3$ & $41.4 \pm 0.5$ & $29.0 \pm 0.4$ \\
\hline 8.0 & 8.0 & 100 & 5 & 0.62 & $68.9 \pm 0.1$ & $27.3 \pm 0.7$ & $44.4 \pm 1.2$ & $28.6 \pm 0.2$ \\
\hline 10.0 & 10.0 & 100 & 5 & 0.71 & $64.6 \pm 0.3$ & $28.2 \pm 1.5$ & $43.2 \pm 1.2$ & $27.6 \pm 0.5$ \\
\hline 2.0 & 2.0 & 121/15 psi & 60 & $0.26(n=3.1)$ & $78.1 \pm 0.2$ & $25.3 \pm 0.2$ & $42.1 \pm 0.2$ & $31.5 \pm 0.1$ \\
\hline 4.0 & 4.0 & 121/15 psi & 60 & 1.20 & $71.2 \pm 0.6$ & $26.6 \pm 0.8$ & $42.9 \pm 1.0$ & $28.8 \pm 0.3$ \\
\hline 6.0 & 6.0 & 121/15 psi & 60 & 1.74 & $63.0 \pm 0.2$ & $30.0 \pm 0.7$ & $46.9 \pm 1.0$ & $26.5 \pm 0.1$ \\
\hline 8.0 & 8.0 & 121/15 psi & 60 & 2.14 & $57.0 \pm 0.6$ & $32.5 \pm 0.0$ & $52.3 \pm 0.0$ & $22.8 \pm 0.0$ \\
\hline 10.0 & 10.0 & 121/15 psi & 60 & 2.43 & $51.2 \pm 0.0$ & $32.8 \pm 0.0$ & $53.5 \pm 0.0$ & $19.5 \pm 0.1$ \\
\hline 2.0 & - & 121/15 psi & 60 & $0.21(n=2.2)$ & $79.0 \pm 0.1$ & $25.5 \pm 0.0$ & $42.4 \pm 0.0$ & $33.2 \pm 0.4$ \\
\hline 4.0 & - & 121/15 psi & 60 & 0.89 & $72.6 \pm 0.8$ & $27.0 \pm 1.1$ & $44.2 \pm 1.2$ & $30.5 \pm 0.2$ \\
\hline 6.0 & - & 121/15 psi & 60 & 1.28 & $64.2 \pm 0.1$ & $31.1 \pm 0.5$ & $48.5 \pm 1.3$ & $27.3 \pm 0.1$ \\
\hline 8.0 & - & 121/15 psi & 60 & 1.56 & $58.5 \pm 0.1$ & $32.2 \pm 0.0$ & $48.9 \pm 0.0$ & $23.9 \pm 1.3$ \\
\hline 10.0 & - & 121/15 psi & 60 & 1.77 & $52.0 \pm 0.3$ & $31.8 \pm 0.0$ & $50.0 \pm 0.0$ & $20.1 \pm 0.1$ \\
\hline - & 2.0 & 121/15 psi & 60 & $0.21(n=2.2)$ & $83.1 \pm 0.4$ & $22.9 \pm 1.2$ & $41.2 \pm 1.8$ & $33.1 \pm 0.3$ \\
\hline- & 4.0 & 121/15 psi & 60 & 0.89 & $79.5 \pm 1.2$ & $22.7 \pm 0.1$ & $42.2 \pm 0.3$ & $33.2 \pm 0.2$ \\
\hline- & 6.0 & 121/15 psi & 60 & 1.28 & $79.3 \pm 1.6$ & $22.2 \pm 0.3$ & $42.0 \pm 0.0$ & $32.6 \pm 0.7$ \\
\hline- & 8.0 & 121/15 psi & 60 & 1.56 & $77.2 \pm 0.4$ & $23.2 \pm 0.4$ & $43.1 \pm 0.8$ & $32.4 \pm 0.2$ \\
\hline- & 10.0 & 121/15 psi & 60 & 1.77 & $76.8 \pm 0.8$ & $23.2 \pm 0.4$ & $43.1 \pm 0.8$ & $31.2 \pm 0.8$ \\
\hline$R^{2}$ & & & & & 0.95 & 0.90 & 0.79 & 0.87 \\
\hline RMSE & & & & & 2.26 & 1.19 & 1.84 & 1.57 \\
\hline Tukey's HSD (P & & & & & 43.34 & 17.84 & 25.5 & 16.07 \\
\hline
\end{tabular}

${ }^{a}$ Modified combined severity factor; ${ }^{b}$ Total sugars including glucose, xylose, galactose, arabinose and mannose; ${ }^{c}$ Total lignin including acid insoluble lignin (AIL) and acid soluble lignin (ASL) after ash correction. Date are average of two replicates. Numbers with \pm values represent standard errors.
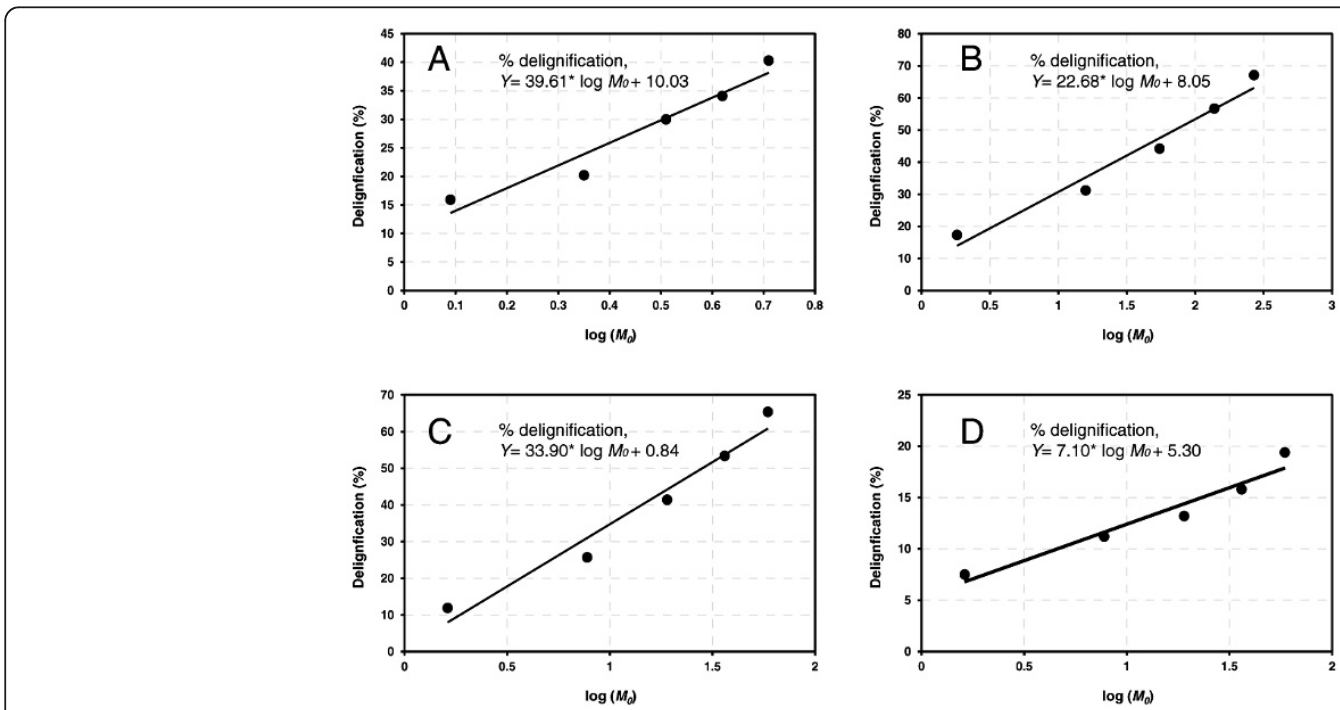

Figure 2 Plot of percent delignification of manure fibers vs modified severity parameter $\left(\log M_{0}\right)$ for alkaline pretreatment treated at. $(\mathrm{A}) 100^{\circ} \mathrm{C}$ using combined $\mathrm{NH}_{3}$ and $\mathrm{NaOH}$, (B) $121^{\circ} \mathrm{C} / 15$ psi using combined $\mathrm{NH}_{3}$ and $\mathrm{NaOH}$, (C) $121^{\circ} \mathrm{C} / 15$ psi using $\mathrm{NaOH}$, and (D) $121^{\circ} \mathrm{C} / 15$ psi using $\mathrm{NH}_{3}$. 

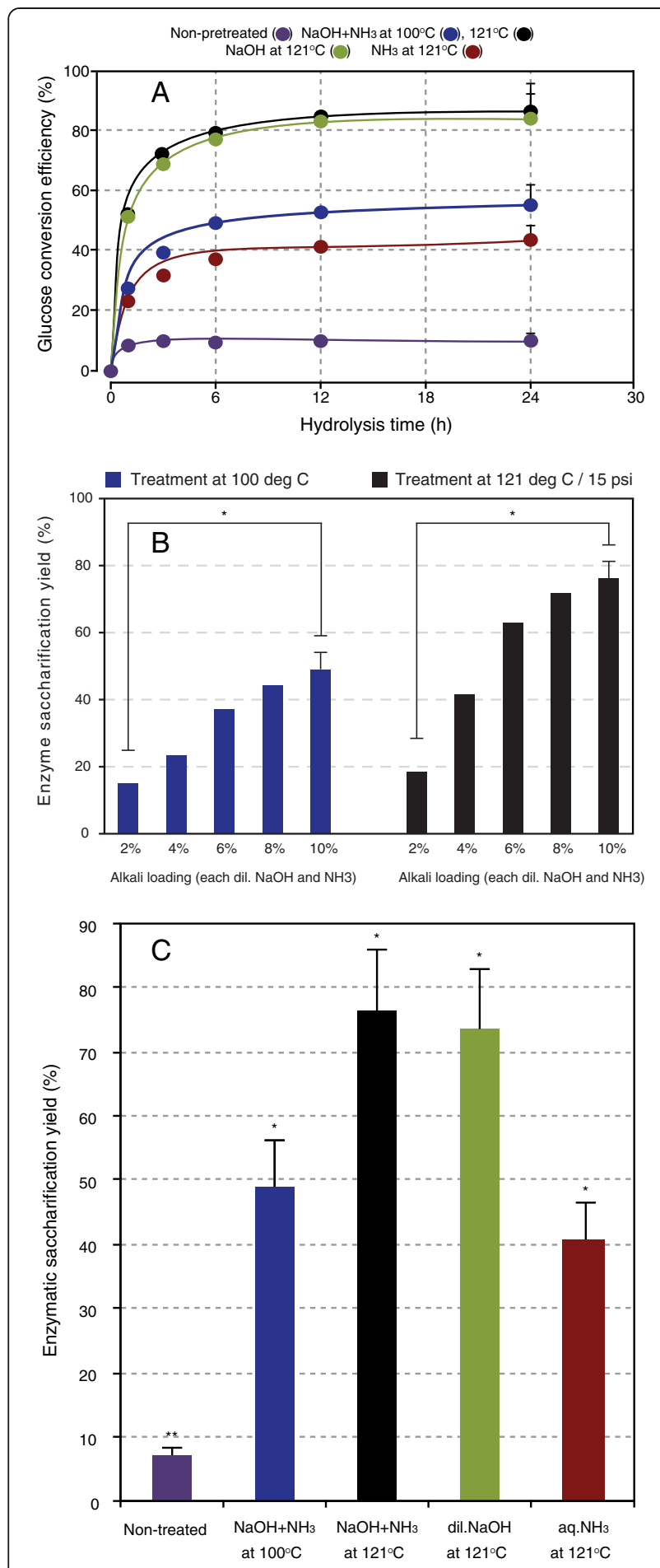

Figure 3 Enzymatic digestibility of manure fibers both non-pretreated and pretreated at $10 \%$ alkali loading under different conditions. (A) Glucose conversion efficiency, (B) total saccharification yield of manure fibers treated under different conditions after $24 \mathrm{~h}$, and (C) total saccharification yield of manure fibers after $24 \mathrm{~h}$. Error bars represent root mean square error. $\left(^{* *}\right)$ Non-significant and $(*)$ significantly different at $95 \%$ confidence level, $p$ value $<0.001$ and hydrogen bonding relationships [61,62]. Studies recognized that alkaline pretreatment causes swelling of cellulose, leading to the decrease of degree of polymerization and crystallinity, and increases the surface area that facilitates more substrate exposed to cellulase attack [48]. However, the poor negative correlation between the cellulose crystallinity index and enzymatic digestion of fibers under different conditions $\left(R^{2}<0.1\right)$ (Figure $5 B-D$ ), might be due to the dissolution of amorphous materials (xylan and lignin) and/or interference of other soluble materials $[63,64]$.

\section{Effect of pretreatment conditions on fiber delignification and enzymatic saccharification}

We carried out a detailed study of the relationship between pretreatment parameters and fiber composition following enzymatic digestion by using a central composite design experiment with 3 dependent factors and 3 different levels (Table 3): 3 alkali loadings $\left(x_{1}\right)$ of 2.0, 4.0 and $6.0 \%$ of each $\mathrm{NaOH}$ and $\mathrm{NH}_{3}, 3$ treatment temperatures $\left(x_{2}\right)$ of 80,100 , and $121^{\circ} \mathrm{C}$, and three residence times $\left(x_{3}\right)$ of 5 , 30, and $60 \mathrm{~min}$. The experimental parameters were selected on the basis of a previous SHAH pretreatment study on PBD manure fiber. The results showed a dependence on the pretreatment conditions of sugars released, mainly hemicellulose which is more vulnerable to chemical attack, and lignin (Table 4). The model identified that, within the studied range of experiments, chemical loading had the most significant effect on both sugar dissolution (regression coefficient, $\left.\beta_{3}=-5.4\right)$ and delignification $\left(\beta_{3}=10.5\right)$. Increasing alkali loadings from 2.0 to $6.0 \%$ led to a decrease in total sugar recovery by $20 \%$ and a decrease in residual lignin by $40 \%$. The correlation coefficient values for the models $\left(R^{2} \geq 0.95\right)$ indicate that a large fraction of the variation in responses results from differences in the independent variables. Although enhanced removal of residual lignin is expected to improve subsequent enzymatic digestibility, the simultaneous loss of residual carbohydrate should decrease the yield of sugars through enzymatic hydrolysis [46].

Following enzymatic saccharification, chemical loading $\left(\beta_{3}=12.6\right)$ had more significant effect than residence time $\left(\beta_{2}=11.0\right)$ or treatment temperature $\left(\beta_{1}=5.9\right)$. Three linear effects and one quadratic effect were observed with subsequent enzymatic digestibility of the treated fibers. An increase in chemical loading from 2.0 to $6.0 \%$ led to a $57 \%$ saccharification yield with $64 \%$ glucose conversion. This may be due to the enhanced removal of enzyme barriers, including residual lignin $(\sim 30 \%)$ and hemicelluloses $(\sim 22 \%)$, and surface modification during pretreatment which improves enzyme accessibility [9]. Linear terms of delignification and enzymatic saccharification correlated positively with the treatment parameters, indicating that these have the greatest effect on substrate deconstruction. 

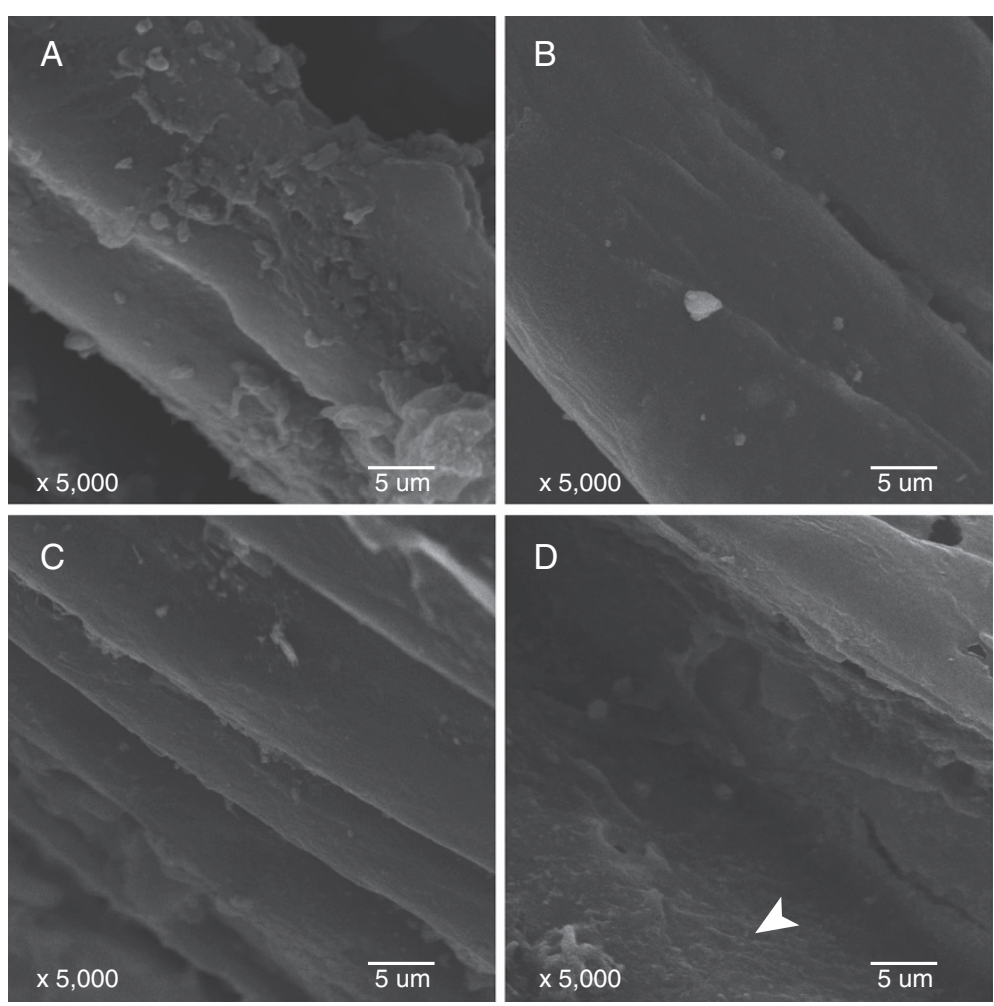

Figure 4 Scanning electron microscope images of manure fibers before and after treatment at $121^{\circ} \mathrm{C}$ and $10 \%$ alkali loading level. (A) non-pretreated (control), (B) pretreated by $\mathrm{NH}_{3}$ alone, (C) pretreated by $\mathrm{NaOH}$ alone, and (D) pretreated by combined $\mathrm{NH}_{3}$ and $\mathrm{NaOH}_{\text {. }}$
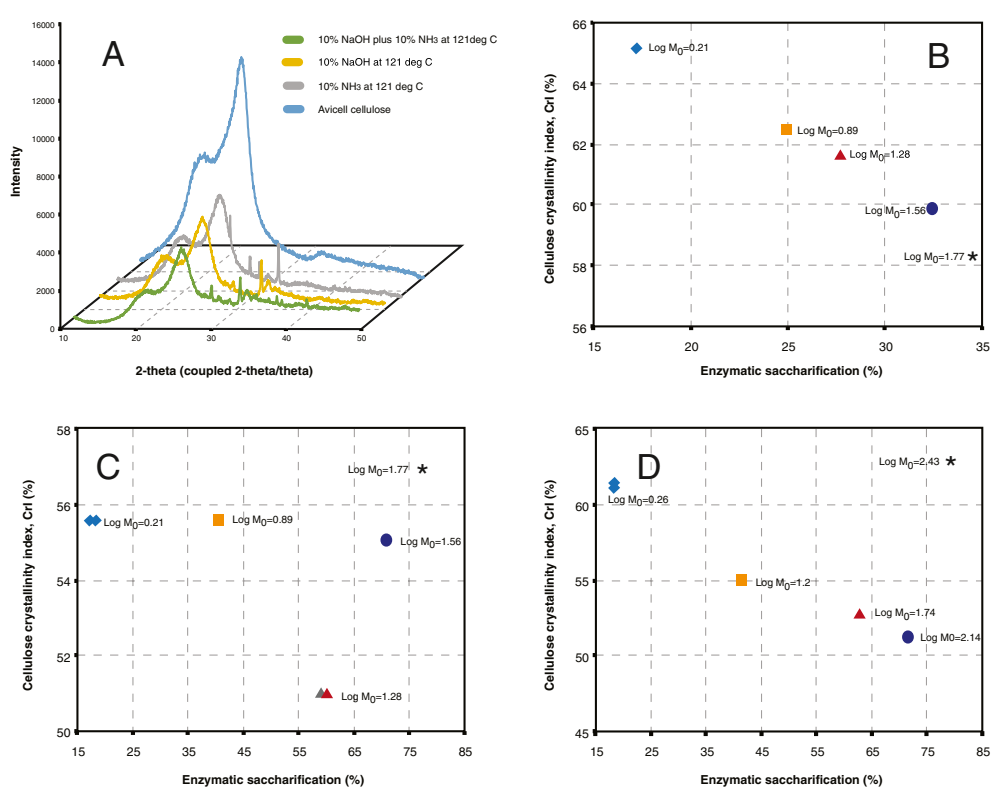

Figure 5 Cellulose crystallinity index (Crl) of alkaline-treated manure fibers and its relationship to the enzymatic digestibility (24 h). (A) powder $\mathrm{X}$-ray diffraction spectrum of fibers after treatment at different conditions, (B) correlation between enzymatic digestibility and Crl of separate $\mathrm{NH}_{3}$ treated fibers, (C) correlation between enzymatic digestibility and $\mathrm{Crl}$ of separate $\mathrm{NaOH}$ treated fibers, and (D) correlation between enzymatic digestibility and $\mathrm{Crl}$ of both $\mathrm{NaOH}$ and $\mathrm{NH}_{3}$ treated fibers, under different conditions. Data are averages of two replicates. 
Table 3 Central composite experimental design and the corresponding pretreatment responses with subsequent enzyme saccharification of post-biogas digestion manure fibers

\begin{tabular}{|c|c|c|c|c|c|}
\hline \multicolumn{3}{|c|}{ Independent variables } & \multicolumn{3}{|c|}{ Dependent variables, $Y$} \\
\hline $\begin{array}{l}a_{\%} \mathrm{NaOH} \text { and } \mathrm{NH}_{3} \\
\text { loading, } \mathrm{gm} / \mathrm{gm} \\
\text { dry fiber, } x_{1}\end{array}$ & $\begin{array}{c}\text { Temperature } \\
\left({ }^{\circ} \mathrm{C}\right), x_{2}\end{array}$ & $\begin{array}{c}\text { Residence } \\
\text { time }(\min ), x_{3}\end{array}$ & $\begin{array}{l}\text { Total sugar } \\
\text { recovery\% }\end{array}$ & $\begin{array}{l}\text { Delignification\% } \\
\text { dry basis }\end{array}$ & Enzyme saccharification $\%$ \\
\hline 8.0 & 100 & 30 & $87.3 \pm 0.0$ & $22.9 \pm 0.3$ & $24.5 \pm 0.8$ \\
\hline 12.0 & 80 & 5 & $87.4 \pm 0.0$ & $25.7 \pm 1.3$ & $19.9 \pm 4.3$ \\
\hline 8.0 & 100 & 30 & $87.3 \pm 0.0$ & $22.9 \pm 0.3$ & $24.5 \pm 0.8$ \\
\hline 12.0 & 121 & 5 & $87.5 \pm 0.4$ & $21.6 \pm 1.1$ & $23.9 \pm 1.2$ \\
\hline 8.0 & 100 & 60 & $86.0 \pm 0.4$ & $26.3 \pm 0.8$ & $34.0 \pm 1.2$ \\
\hline 4.0 & 121 & 5 & $94.6 \pm 0.1$ & $5.9 \pm 0.9$ & $2.5 \pm 0.4$ \\
\hline 12.0 & 80 & 60 & $82.7 \pm 0.6$ & $32.8 \pm 0.5$ & $44.5 \pm 1.0$ \\
\hline 8.0 & 100 & 5 & $91.5 \pm 0.1$ & $17.1 \pm 0.2$ & $16.2 \pm 0.1$ \\
\hline 8.0 & 100 & 30 & $87.3 \pm 0.0$ & $22.9 \pm 0.3$ & $24.5 \pm 0.8$ \\
\hline 12.0 & 100 & 30 & $79.4 \pm 0.1$ & $37.1 \pm 0.3$ & $36.5 \pm 3.8$ \\
\hline 4.0 & 80 & 60 & $93.4 \pm 0.1$ & $12.2 \pm 0.1$ & $10.9 \pm 0.1$ \\
\hline 8.0 & 121 & 30 & $80.2 \pm 0.8$ & $30.3 \pm 1.0$ & $49.0 \pm 2.8$ \\
\hline 12.0 & 121 & 60 & $73.3 \pm 0.4$ & $44.3 \pm 0.8$ & $59.0 \pm 0.5$ \\
\hline 8.0 & 100 & 30 & $87.3 \pm 0.0$ & $22.9 \pm 0.3$ & $24.5 \pm 0.8$ \\
\hline 4.0 & 100 & 30 & $93.1 \pm 0.1$ & $10.0 \pm 1.3$ & $13.7 \pm 0.4$ \\
\hline 4.0 & 121 & 60 & $88.3 \pm 0.1$ & $17.5 \pm 1.3$ & $27.5 \pm 0.2$ \\
\hline 4.0 & 80 & 5 & $95.2 \pm 0.1$ & $11.1 \pm 1.1$ & $3.1 \pm 0.2$ \\
\hline 8.0 & 80 & 30 & $89.5 \pm 0.1$ & $21.1 \pm 0.0$ & $24.8 \pm 0.5$ \\
\hline 8.0 & 100 & 30 & $87.3 \pm 0.0$ & $22.9 \pm 0.3$ & $24.5 \pm 0.8$ \\
\hline
\end{tabular}

${ }^{a}$ Percentage of each $\mathrm{NaOH}$ and $\mathrm{NH}_{3}$ added to the dry manure solids. Data are average of two replicates. Numbers with \pm values represent standard errors.

The second most important parameter affecting the overall process was the residence time [65]. This suggests that longer treatment times reduce fiber recalcitrance that limits sugar degradation [66] and improve energy utilization.

\section{Conclusions}

In the present study, enzyme recalcitrant post-biogas digestion (PBD) manure fibers were subjected to an innovative pretreatment method involving combined alkalis (dilute sodium hydroxide and aqueous ammonia). The effects of

Table 4 Statistical analysis of the effect of pretreatment parameters on manure fiber pretreatment recovery and following enzymatic saccharification

\begin{tabular}{|c|c|c|c|c|c|c|}
\hline & \multicolumn{2}{|c|}{ Total sugar recovery } & \multicolumn{2}{|c|}{ Delignification } & \multicolumn{2}{|c|}{ Enzymatic saccharification } \\
\hline${ }^{a} R^{2}$ & \multicolumn{2}{|c|}{0.96} & \multicolumn{2}{|c|}{0.97} & \multicolumn{2}{|c|}{0.95} \\
\hline Prob. $>$ F & \multicolumn{2}{|c|}{$<0.0001^{*}$} & \multicolumn{2}{|c|}{$<0.0001^{*}$} & \multicolumn{2}{|c|}{$<0.0001^{*}$} \\
\hline Terms & Estimate & ${ }^{\mathrm{b}}$ Prob. $>|\mathrm{t}|$ & Estimate & ${ }^{b}$ Prob. $>|t|$ & Estimate & ${ }^{b}$ Prob. $>\mid t$ \\
\hline Temp $\left({ }^{\circ} \mathrm{C}\right)$ & -2.43 & $0.0011^{*}$ & 1.66 & 0.061 & 5.88 & $0.0035^{*}$ \\
\hline Time (min) & -3.26 & $0.0001^{*}$ & 5.17 & $<0.0001^{*}$ & 11.0 & $<0.0001^{*}$ \\
\hline Chemical loading (\% on dry solids) & -5.42 & $<0.0001^{*}$ & 10.4 & $<0.0001^{*}$ & 12.6 & $<0.0001^{*}$ \\
\hline Temp x Temp & -1.50 & 0.1613 & 1.43 & 0.360 & 7.13 & $0.0345^{*}$ \\
\hline Time $x$ Time & 2.41 & $0.0372^{*}$ & -2.61 & 0.113 & -4.65 & 0.139 \\
\hline Chemical loading $\times$ Chemical loading & -0.079 & 0.938 & -0.76 & 0.620 & -4.64 & 0.140 \\
\hline Temp x Time & -1.73 & $0.015^{*}$ & 3.26 & $0.0046^{*}$ & 3.47 & 0.0681 \\
\hline Temp x Chemical loading & -0.44 & 0.463 & 0.91 & 0.322 & 0.33 & 0.848 \\
\hline Time x Chemical loading & -1.37 & $0.0414^{*}$ & 2.14 & $0.0363^{*}$ & 3.36 & 0.0755 \\
\hline
\end{tabular}

${ }^{a}$ Correlation coefficient; ${ }^{b}$ p-value of the two-tailed test; ${ }^{*}$ Numbers with asterisk indicate that the term has a significant effect at $95 \%$ confidence level. 
pretreatment conditions were studied, including alkali loading on fibers, treatment temperature, and residence time. The results show that the dual alkali treatment improves fiber delignification (maximum 67.1\%) and subsequent enzymatic digestion (maximum of $76.3 \%$ ) of PBD manure fibers. Furthermore, the pretreatment alters the surface structural characteristics of the fiber apparently making them more prone to enzyme attack for enhanced sugar release. A positive factor in the economic viability of PBD manure fiber for cellulosic bioethanol production, is the high availability and relatively low cost of the feedstock. On the other hand, the costs of chemical consumption need to be taken into account, although these could be mitigated in part by recovery and reuse of the gas phase ammonia formed during the alkali reaction. In addition, it may be possible to improve the efficiency of the process by combined maceration (mechanical milling) and alkaline pretreatment with both $\mathrm{NaOH}$ and $\mathrm{NH}_{3}$, and studies to evaluate this approach are ongoing.

\section{Methods}

Manure samples

Post-biogas digestion manure fibers were collected from Maple Leaf Dairy Farm, Cleveland, Wisconsin. The cattle feed was a mixture of alfalfa, corn silage and other proteins according to the National Research Council nutrient requirements of dairy cattle. The anaerobic digestion was running with a hydraulic retention time of 14-15 days at $35-40^{\circ} \mathrm{C}$. The slurry containing undigested solids were separated by a $2.0 \mathrm{~mm}$ screen screw press. The collected fibers contained $60-65 \%$ moisture; they were air-dried and ground with a laboratory hammer mill (Christy \& Norris Ltd., England, Model No. 1024XC) and then sieved. The fiber fraction within 40-50 mesh was used for the analysis.

\section{Combined alkaline pretreatment}

Sodium hydroxide (50\% wt. Fisher Catalog No. SS2544) and ammonium hydroxide (30\% wt. Fisher Catalog No. 125) were used pretreatment. Weighed quantities of fiber in $50 \mathrm{ml}$ Oak Ridge thermal resistant tubes (Fisher Catalog No. 05-563-10G) were treated with $\mathrm{NaOH}$ and/or $\mathrm{NH}_{3}$ (at different loadings of each alkali 2-10\% w/w) at room temperature for $2 \mathrm{~h}$, followed by heating at 100 or $121^{\circ} \mathrm{C}$ for $1 \mathrm{~h}$. The solid-to-liquid ratio was maintained at 1:7. After pretreatment, the supernatant was collected following centrifugation at 3,900 rpm (Eppendorf 510R) for $20 \mathrm{~min}$, and the solid residues obtained were thoroughly washed with water until the $\mathrm{pH}$ reached neutrality. Finally, the solid residues were dried in a freeze-dryer (VirTis freezemobile $35 \mathrm{ES}$ ) and stored at $-80^{\circ} \mathrm{C}$ (New Brunswick U-700 freezer).

\section{Enzymatic digestibility}

Enzyme saccharification of fibers, both non-treated (control) and chemically treated, was carried out according to the standard NREL procedure (LAP 42629). Saccharification was conducted in $50 \mathrm{~mL}$ Falcon tubes at $2.0 \%$ $(\mathrm{w} / \mathrm{v})$ substrate consistency level using sodium acetate buffer $\mathrm{pH}$ 4.8. Tetracycline antibiotic was added at $0.02 \%$ $(\mathrm{w} / \mathrm{v})$ to prevent microbial contamination, Enzymes used in this study, Cellic CTec2 (cellulase complex containing cellulose and $\beta$-glucosidase) and Cellic HTec2 (hemicellulases including xylanase), were generously provided by Novozymes (Franklinton, NC). The Cellic CTec2 and Cellic HTec2 loadings on substrates were $5 \%$ and $2 \% \mathrm{w} / \mathrm{w}$ (gm enzyme/gm dry fiber), respectively. Substrates were pre-incubated at $50^{\circ} \mathrm{C}$ in sodium acetate buffer for $24 \mathrm{~h}$ prior to the addition of enzymes. Hydrolysis was conducted at $50^{\circ} \mathrm{C}$ in a shaker (New Brunswick Scientific Excella E24) at $200 \mathrm{rpm}$ for $24 \mathrm{~h}$. Samples were collected intermittently and analyzed for sugar concentration using High Performance Liquid Chromatography (HPLC) System (Agilent Technologies 1200 series). The HPLC was equipped with Bio-rad deashing micro-guard column (Cat No. 125-0118, Bio-Rad, CA) and Agilent Hi-Plex H (7.7 × $300 \mathrm{~mm}, 8 \mu \mathrm{m})$ analytical column operated at $60^{\circ} \mathrm{C}$ with $5 \mathrm{mM} \mathrm{H}_{2} \mathrm{SO}_{4}$ mobile phase at the flow rate of $0.7 \mathrm{~mL} / \mathrm{min}$. A refractive index detector (Agilent Technologies) was operated at $55^{\circ} \mathrm{C}$. The mobile phase was filtered through a $0.22 \mu \mathrm{m}$ nylon membrane (Millipore Corporation, MA) and degassed. The released glucose and other sugars (xylose, galactose, arabinose and mannose) at each time interval were used to calculate the glucose conversion and saccharification efficiency of the substrate as a percentage to the potential sugars available in the substrates. Each data point was the average of two replicates.

\section{Analytical methods}

Manure fiber moisture, extractives and ash contents were determined according to National Renewable Energy Laboratory (NREL) analytical procedures LAP 012, LAP 010 and LAP 005, respectively. Similarly, carbohydrate analysis of non-treated and chemically pretreated manure fiber was carried out according to NREL procedure LAP 009. Samples $(0.3 \mathrm{~g})$ were weighed $\left(W_{1}\right)$ in a $5 \mathrm{ml}$ centrifuge tube and hydrolyzed with $3 \mathrm{ml} 72 \% \mathrm{H}_{2} \mathrm{SO}_{4}$ (v/v) for $60 \mathrm{~min}$. The hydrolyzate was diluted to $4 \%$ acid concentration $(\mathrm{v} / \mathrm{v})$ and autoclaved for $60 \mathrm{~min}$ at $121^{\circ} \mathrm{C}$ at 15 psi. The hydrolysis solution was vacuum filtered through the previously weighed filtering crucible. The filtrate was collected $\left(F_{1}\right)$ and analyzed for carbohydrate and acid soluble lignin determination. Carbohydrate content, including glucose, xylose, galactose, arabinose, and mannose sugars, were analyzed on an HPLC System (Agilent Technologies 1200 series) equipped with 
a Bio-Rad deashing micro-guard column (Cat No. 125-0118, Bio-Rad, CA) and an Agilent Hi-Plex $\mathrm{H}$ $(7.7 \times 300 \mathrm{~mm}, 8 \mu \mathrm{m})$ analytical column with a mobile phase of $5 \mathrm{mM} \mathrm{H}_{2} \mathrm{SO}_{4}$ operated at a flow rate of $0.7 \mathrm{~mL} / \mathrm{min}$ at $60^{\circ} \mathrm{C}$. The mobile phase was filtered through a $0.22 \mu \mathrm{m}$ nylon membrane (Millipore Corporation, MA) and degassed, and peaks were detected by a refractive index detector (Agilent Technologies) operated at $55^{\circ} \mathrm{C}$.

Acid insoluble lignin was calculated gravimetrically as acid-insoluble residue after correction for ash content. The lignin collected during filtration was washed with water and dried overnight in an oven at $105^{\circ} \mathrm{C}$. The weight of the crucible with lignin was recorded $\left(W_{2}\right)$, and the sample was ashed in muffle furnace for $4 \mathrm{~h}$ at $575^{\circ} \mathrm{C}$. Finally, the weight of the crucible with ash content was recorded $\left(W_{3}\right)$. Acid insoluble lignin (AIL) content of the manure fiber was calculated by the following equation:

$$
A I L(\%)=\frac{\left(W_{2}-W_{3}\right)}{W_{1} \times m_{i}} \times 100
$$

where $m_{i}$ is the initial moisture content of the manure sample. The filtrate $F_{1}$ was measured for the acid soluble lignin at $208 \mathrm{~nm}$ using UV/Vis spectroscopy (Agilent Cary 60) with 4\% (v/v) sulfuric acid as reference blank.

\section{Lignin monomer composition}

Manure fiber lignin composition was determined by derivatization followed by reductive cleavage method [67].

\section{Colorimetric assay of uronic acid}

A $m$-hydroxydiphenyl colorimetric assay was followed for the determination of uronic acid content [39,68]. All chemicals were purchased from Sigma Aldrich (St. Louis, MO) and used as such. $200 \mu \mathrm{L}$ of the acid hydrolyzate filtrate $\left(F_{1}\right)$ was added to $1.2 \mathrm{~mL} \mathrm{H}_{2} \mathrm{SO}_{4}$-tetraborate solution ( $476.8 \mathrm{mg}$ sodium tetraborate dissolved in $500 \mathrm{~mL} 18 \mathrm{M} \mathrm{H}_{2} \mathrm{SO}_{4}$ ). Followed by, heating in a boiling water bath for $5 \mathrm{~min}$ and ice cooled. $20 \mu \mathrm{L}$ of $0.15 \% \mathrm{~m}$ hydroxydiphenyl reagent (22.5 mg 3-phenylphenol dissolved in $15 \mathrm{~mL} 0.5 \% \mathrm{w} / \mathrm{v} \mathrm{NaOH}$ ) was added to the reaction mixture and vortexed immediately until to get a dark pink color. Finally, the reagent mixture was read after the original color development at $520 \mathrm{~nm}$ using UV/Vis spectrophotometer (Agilent Cary 60). The uronic acid content was calculated from the OD value using the glucouronic acid/galacturonic acid calibration curve.

\section{Scanning electron microscopy}

The manure residues were collected after pretreatment at different conditions and washed with distilled water and vacuum dried. The dry samples both non-treated and chemically treated were coated with gold in a SeeVac Auto conductavac IV sputter coater and scanned by scanning electron microscope (Hitachi S-570 $\mathrm{LaB}_{6}$, Tokyo, Japan) at accelerating voltage of $10.0 \mathrm{kV}$ (12.7 stub size).

\section{Crystallinity index measurement}

Cellulose crystallinity index $(\mathrm{CrI})$ of both treated and non-treated manure fiber was measured by powder Xray diffraction (PXRD) method using a Bruker D2 Phaser instrument (Bruker AXS Inc., Madison, WI). Dried samples $(\sim 0.5 \mathrm{~g})$ were ground to a powder $<100 \mu \mathrm{m}$ size and pressed into $40-\mathrm{mm}$ diameter pellets. The pellets were measured in Bragg-Brentano geometry using a LynxEye detector with $4^{\circ}$ opening. $\mathrm{Ni}$-filtered copper radiation was generated at $30 \mathrm{kV} / 10 \mathrm{~mA}$, and the pellets were scanned from $5^{\circ}$ to $50^{\circ}$ by $0.02^{\circ}$ steps at $1 \mathrm{~s}$ each. The divergence slit was $0.6 \mathrm{~mm}$, and the primary and secondary soller slits were $2.5^{\circ}$ and $4^{\circ}$, respectively. TOPAS software version 4.2 was used to calculate the CrI of samples from the ratio of the area of all crystalline peaks to the total area by the deconvolution method [69].

\section{Elemental analyses of manure fiber}

Elemental analysis of the manure fiber was carried out by using a wavelength dispersive X-ray fluorescence (WDXRF) spectrophotometer S8 Tiger (Bruker AXS Inc., Madison, WI). About $10 \mathrm{~g}$ of an air-dried, non-pretreated PBD manure fiber sample was ground with inert binding material (amyl acetate, 5\% collodion) (Bruker AXS GmbH, Germany) at a 5:1 ratio to assist grinding performance, increase pellet stability, and reduce material rewelding in vessel. This was followed by compression pressing of the powder $\left(30 \mathrm{KN} / \mathrm{m}^{2}\right)$ for $15 \mathrm{~s}$ in a $40-\mathrm{cm}$ (dia) aluminum cup. The XRF spectrophotometer was equipped with 2 collimators $\left(0.23^{\circ}\right.$ and $\left.0.46^{\circ}\right)$ and a set of 6 analyzer crystals (XS-GE-C, XS-CEM, XS-55, PET, LiF200 and LiF220). The measurement method used $27 \mathrm{kV} / 150 \mathrm{~mA}$ excitation for light elements and $60 \mathrm{kV} / 67 \mathrm{~mA}$ excitation for heavy elements using a Rhodium tube. The elemental composition was calculated by using QUANT-EXPRESS calibration (Bruker AXS GmbH, Germany).

\section{Severity parameter and statistical data analysis}

The severity parameter $\left(R_{O}\right)$, a factor intended to quantify the energy intensity or severity of a pretreatment strategy, was initially defined by Overend and Chornet (1987) to relate temperature and time for steam explosion pretreated based on the assumption that the pretreatment effect follows first-order kinetics and obeys the Arrhenius equation [70]. Chum et al., (1990) later developed a modified severity parameter to use for sulfuric acid pretreatment that relates concentration with 
an introduced arbitrary constant, temperature and residence time as follows [71]:

$$
M_{0}=t \times C^{n} \times \exp \left[\frac{\left(T_{r}-T_{b}\right)}{14.75}\right]
$$

Where $M_{O}$ is the modified severity parameter; $t$ is the residence time ( $\mathrm{min}) ; \mathrm{C}$ is the concentration of chemical (wt.\%); $T_{r}$ is the reaction temperature; $T_{b}$ is the base temperature; $\mathrm{n}$ is the arbitrary constant. Silverstein et al. (2007) used the above equation for sodium hydroxide pretreatment by replacing the acid concentration with the alkali concentration [41]. Similarly, modified severity parameters of the alkaline pretreatment using $\mathrm{NaOH}$ and/or $\mathrm{NH}_{3}$ were calculated from the above equation at different $\mathrm{n}$-values obtained by data training while keeping positive $\log \left(M_{0}\right)$.

The more detailed relationship between the pretreatment parameters and pretreatment recovery following enzymatic digestion (dependent variables) of the PBD manure fiber was explored using less runs by using central composite design experiments [64,72]. Statistical software SAS JMP Pro version 10 was used for the design of experiments and to analyze the experimental data obtained. $3 \times 3$ central composite design experiments comprised a total of 19 runs with different combinations of pretreatment conditions derived by altering the three independent variables, alkali loading both $\mathrm{NaOH}$ and $\mathrm{NH}_{3}$ (2-10\% of each loading on dry manure fiber), treatment temperature $\left(80,100\right.$ and $\left.120^{\circ} \mathrm{C}\right)$, and residence time (5, 30 and $60 \mathrm{~min}$ ). The parameter levels were selected based on the previous study. The experimental data obtained were fitted to the following second order polynomial regression equation to identify the key variables:

$$
Y=\beta_{0}+\sum_{i=1}^{n} \beta_{i} x_{i}+\sum_{i=1}^{n} \beta_{i i} x_{i}^{2}+\sum_{i=1}^{n} \sum_{j=1}^{n} \beta_{i j} x_{i} x_{j}
$$

Where $Y$ is the measured response (carbohydrate recovery, delignification efficiency and subsequent enzymatic digestibility); $i, j$ are the linear and quadratic coefficients respectively; $\beta_{0}$ is the regression coefficient; $x$ is the independent variable (alkali loading, temperature and residence time). The quality of model fit was expressed by the coefficient of determination, $\mathrm{R}^{2}$ value. Model terms were evaluated based on the probability, p value with $95 \%$ confidence level.

\section{Additional file}

Additional file 1: Figure S1. Correlation plot of experimental and model predicted values of percent delignification of manure fibers pretreated at: (A) $100^{\circ} \mathrm{C}$ using combined $\mathrm{NH}_{3}$ and $\mathrm{NaOH}$, (B) $121^{\circ} \mathrm{C} / 15 \mathrm{psi}$ using combined $\mathrm{NH}_{3}$ and $\mathrm{NaOH}$, (C) $121^{\circ} \mathrm{C} / 15$ psi using $\mathrm{NaOH}$, and (D) $121^{\circ} \mathrm{C} / 15$ psi using $\mathrm{NH}_{3}$.

\section{Abbreviations}

PBD: Post-biogas digestion; $\mathrm{NaOH}$ : Sodium hydroxide; $\mathrm{NH}_{3}$ : aqueous ammonia; SHAH: Sodium hydroxide and ammonium hydroxide.

\section{Competing interests}

The authors declare that they have no competing interests.

\section{Authors' contributions}

SE and TR designed the research with SE performing the experiments; SE, $A R$, TR, and JM analyzed the data and wrote the paper. All authors read and approved the final manuscript.

\section{Acknowledgements}

We gratefully acknowledge the United States Department of Agriculture-National Institute of Food and Agriculture for its financial support (USDA BRDI Grant number 2012-10006-19423). The authors thank GLBRC UW-Madison (Ruwan Ranatunga) for generously provided a Corn Stover-2010 sample for the comparison study. The authors thank Dharshana Padmakshan and Steven D. Karlen (GLBRC UW-Madison) for providing assistance with lignin monomer detection of manure fiber.

\section{Author details}

'Department of Biological Systems Engineering, 460 Henry Mall, University of Wisconsin-Madison, Madison, WI 53706, USA. ${ }^{2}$ Soil Net LLC, 560 Enterprise Ave, Belleville, WI 53508, USA. ${ }^{3}$ Department of Biochemistry, 433 Babcock Drive, University of Wisconsin-Madison, Madison, WI 53706, USA.

Received: 22 March 2014 Accepted: 12 May 2014

Published: 20 May 2014

\section{References}

1. Energy Perspectives: Fossil fuels dominate U.S. energy consumption. In Book Energy Prespectives: Fossil fuels dominate U.S. energy consumption. Washington, DC: Annual Energy Review-U.S. Energy Information and Administration; 2012

2. International Energy Agency: Energy Statistics of OECD countries. In Book Energy Statistics of OECD countries. Moscow: International Energy Agency Statistics; 2013.

3. Simmons BA, Loque D, Blanch HW: Next-generation biomass feedstocks for biofuel production. Genome Biol 2008, 9:242.241-242.246.

4. Lynd LR, Cushman JH, Nichols RJ, Wyman CE: Fuel Ethanol from Cellulosic Biomass. Science 1991, 251:1318-1323.

5. Wyman CE: What is (and is not) vital to advancing cellulosic ethanol. Trends Biotechnol 2007, 25:153-157.

6. Slade R, Bauen A, Shah N: The greenhouse gas emissions performance of cellulosic ethanol supply chains in Europe. Biotechnol Biofuels 2009, 2:1-19.

7. Himmel ME, Ding SY, Johnson DK, Adney WS, Nimlos MR, Brady JW, Foust TD: Biomass recalcitrance: Engineering plants and enzymes for biofuels production. Science 2007, 315:804-807.

8. Pan XJ, Xie D, Gilkes N, Gregg DJ, Saddler JN: Strategies to enhance the enzymatic hydrolysis of pretreated softwood with high residual lignin content. Appl Biochem Biotechnol 2005, 121:1069-1079.

9. Chandra RP, Bura R, Mabee WE, Berlin A, Pan X, Saddler JN: Substrate pretreatment: The key to effective enzymatic hydrolysis of lignocellulosics? Adv Biochem Eng Biot 2007, 108:67-93.

10. Hu G, Heitmann JA, Rojas OJ: Feedstock Pretreatment Strategies for Producing Ethanol from Wood, Bark, and Forest Residues. Bioresources 2008, 3:270-294.

11. Betancur GJV, Pereira N: Sugar cane bagasse as feedstock for second generation ethanol production. Part II: Hemicellulose hydrolysate fermentability. Electron J Biotechnol 2010, 13:1-11.

12. Silva NLC, Betancur GJV, Vasquez MP, Gomes ED, Pereira N: Ethanol Production from Residual Wood Chips of Cellulose Industry: Acid Pretreatment Investigation, Hemicellulosic Hydrolysate Fermentation, and Remaining Solid Fraction Fermentation by SSF Process. Appl Biochem Biotechnol 2011, 163:928-936. 
13. Vasquez MP, da Silva JNC, de Souza MB, Pereira N: Enzymatic hydrolysis optimization to ethanol production by simultaneous saccharification and fermentation. App/ Biochem Biotechnol 2007, 137:141-153.

14. Sun Y, Cheng JY: Hydrolysis of lignocellulosic materials for ethanol production: a review. Bioresource Technol 2002, 83:1-11.

15. Sarkar N, Ghosh SK, Bannerjee S, Aikat K: Bioethanol production from agricultural wastes: An overview. Renew Energ 2012, 37:19-27.

16. Yue ZB, Teater C, Liu Y, MacLellan J, Liao W: A Sustainable Pathway of Cellulosic Ethanol Production Integrating Anaerobic Digestion With Biorefining. Biotechnol Bioeng 2010, 105:1031-1039.

17. Liao W, Liu Y, Liu CB, Wen ZY, Chen SL: Acid hydrolysis of fibers from dairy manure. Bioresource Technol 2006, 97:1687-1695.

18. Wen ZY, Liao W, Chen SL: Hydrolysis of animal manure lignocellulosics for reducing sugar production. Bioresource Technol 2004, 91:31-39.

19. Chen S, Wen Z, Liao W, Liu C, Kincaid RL, Harrison JH, Elliott DC, Brown MD, Stevens DJ: Studies into using manure in a biorefinery concept. Appl Biochem Biotech 2005, 121:999-1015.

20. Teater C, Yue ZB, MacLellan J, Liu Y, Liao W: Assessing solid digestate from anaerobic digestion as feedstock for ethanol production. Bioresource Technol 2011, 102:1856-1862

21. Gollehon N, Caswell M, Ribaudo M, Kellogg B, Lander C: Confined animal production and manure nutrients. J Agr Resour Econ 2000, 25:726-726.

22. United States Department of Agriculture: Farms, Land in Farms, and Livestock Operations. In Book Farms, Land in Farms, and Livestock Operations. Washington, DC: USDA National Agricultural Statistics Service; 2009.

23. Yadav A, Gupta R, Garg VK: Organic manure production from cow dung and biogas plant slurry by vermicomposting under field conditions. Int J Recycling Organic Waste in Agric 2013, 2:21.

24. Yadvika S, Sreekrishnan TR, Kohli S, Rana V: Enhancement of biogas production from solid substrates using different techniques--a review. Bioresour Technol 2004, 95:1-10.

25. Alvarez R, Villca S, Lidén G: Biogas production from llama and cow manure at high altitude. Biomass Bioenergy 2006, 30:66-75

26. Iyagba ET, Mangibo IA, Mohammad YS: The study of cow dung as co-substrate with rice husk in biogas production. Scientific Res \& Essay 2009, 4:861-866.

27. Petersen SO, Sommer SG, Beline F, Burton C, Dach J, Dourmad JY, Leip A, Misselbrook T, Nicholson F, Poulsen HD, et al: Recycling of livestock manure in a whole-farm perspective. Livest Sci 2007, 112:180-191.

28. Miller DN, Berry ED: Cattle feedlot soil moisture and manure content: 1. Impacts on greenhouse gases, odor compounds, nitrogen losses, and dust. J Environ Qual 2005, 34:644-655.

29. Johnson GA, Davis JG, Qian YL, Doesken KC: Topdressing turf with composted manure improves soil quality and protects water quality. Soil Sci Soc Am J 2006, 70:2114-2121.

30. Olson BM, Papworth LW: Soil chemical changes following manure application on irrigated alfalfa and rainfed timothy in southern Alberta. Can J Soil Sci 2006, 86:119-132.

31. Spelter H, Winandy J, Zauche T: Anaerobically Digested Bovine Biofiber as a Source of Fiber for Particleboard Manufacturing: An Economic Analysis. Bioresources 2008, 3:1256-1266.

32. Tambone F, Genevini P, D'Imporzano G, Adani F: Assessing amendment properties of digestate by studying the organic matter composition and the degree of biological stability during the anaerobic digestion of the organic fraction of MSW. Bioresource Technol 2009, 100:3140-3142.

33. Kissinger WF, Koelsch RK, Erickson GE, Klopfenstein TJ: Characters of manure harvested from beef cattle feedlots. Appl Eng Agric 2007, 23:357-365.

34. Larney FJ, Ellert BH, Olson AF: Carbon, ash and organic matter relationships for feedlot manures and composts. Can J Soil Sci 2005 85:261-264

35. Reinertsen SA, Elliott LF, Cochran VL, Campbell GS: Role of Available Carbon and Nitrogen in Determining the Rate of Wheat Straw Decomposition. Soil Biol Biochem 1984, 16:459-464.

36. Hsu TA: Pretreament of biomass. In Handbook on Bioethanol: Production and Utilization. Edited by Wyman C. Washington, DC: Taylor \& Francis; 1996:179-195.

37. Rahikainen $J \mathrm{~L}$, Martin-Sampedro R, Heikkinen H, Rovio S, Marjamaa K, Tamminen T, Rojas OJ, Kruus K: Inhibitory effect of lignin during cellulose bioconversion: The effect of lignin chemistry on non-productive enzyme adsorption. Bioresource Technol 2013, 133:270-278.

38. Kumar P, Barrett DM, Delwiche MJ, Stroeve P: Methods for Pretreatment of Lignocellulosic Biomass for Efficient Hydrolysis and Biofuel Production. Ind Eng Chem Res 2009, 48:3713-3729.
39. Elumalai S, Tobimatsu Y, Grabber JH, Pan XJ, Ralph J: Epigallocatechin gallate incorporation into lignin enhances the alkaline delignification and enzymatic saccharification of cell walls. Biotechnol Biofuels 2012, 5:59-71.

40. Chen Y, Stevens MA, Zhu YM, Holmes J, Xu H: Understanding of alkaline pretreatment parameters for corn stover enzymatic saccharification. Biotechnol Biofuels 2013, 6:8-17.

41. Silverstein RA, Chen Y, Sharma-Shivappa RR, Boyette MD, Osborne J: A comparison of chemical pretreatment methods for improving saccharification of cotton stalks. Bioresour Technol 2007, 98:3000-3011.

42. Kim TH, Kim JS, Sunwoo C, Lee YY: Pretreatment of corn stover by aqueous ammonia. Bioresource Technol 2003, 90:39-47.

43. Kim TH, Lee YY: Pretreatment and fractionation of corn stover by ammonia recycle percolation process. Bioresource Technol 2005, 96:2007-2013.

44. Kim TH, Lee $Y Y$ : Pretreatment of corn stover by soaking in aqueous ammonia. Appl Biochem Biotech 2005, 121:1119-1131.

45. Yue ZB, Teater C, MacLellan J, Liu Y, Liao W: Development of a new bioethanol feedstock - Anaerobically digested fiber from confined dairy operations using different digestion configurations. Biomass Bioenerg 2011, 35:1946-1953.

46. Gupta $R$, Lee $Y Y$ : Investigation of biomass degradation mechanism in pretreatment of switchgrass by aqueous ammonia and sodium hydroxide. Bioresource Technol 2010, 101:8185-8191.

47. $\mathrm{Xu} \mathrm{JL}$, Cheng JJ: Pretreatment of switchgrass for sugar production with the combination of sodium hydroxide and lime. Bioresource Techno/ 2011, 102:3861-3868.

48. Chang VS, Holtzapple MT: Fundamental factors affecting biomass enzymatic reactivity. Appl Biochem Biotech 2000, 84-6:5-37.

49. Parsons TR, Maita Y, Lalli CM: A manual of chemical and biological methods for seawater analysis. Paris: Pergamon Press; 1984

50. McCabe WL, Smith JC, Harriott P: Operations involving particulate solids. In Unit Operations of Chemical Engineering. 5th edition. Edited by McCabe WL, Smith JC, Harriot P. Singapore: McGraw Hill; 1993:925.

51. Humbird R, Davis R, Tao L, Kinchin C, Hsu D, Aden A, Schoen P, Lukas J, Olthof B, Worley M, Sexton D, Dudgeon D: Dilute-Acid Pretreatment and Enzymatic Hydrolysis of Corn Stover. In Process Design and Economics for Biochemical Conversion of Lignocellulosic Biomass to Ethanol. 303rd edition. National Renewable Energy Laboratory /TP-5100-47764, Golden, CO; 2011:275-3000.

52. Bhatia $L$, Johri $S$, Ahmad R: An economic and ecological perspective of ethanol production from renewable agro waste: a review. AMB Express 2012, 2:1-19.

53. Fox SC, McDonald AG: Chemical and Thermal Characterization of Three Industrial Lignins and Their Corresponding Lignin Esters. Bioresources 2010, 5:990-1009.

54. Daystar JS, Venditti RA, Gonzalez R, Jameel H, Jett M, Reeb CW: Impacts of Feedstock Composition on Alcohol Yields and Greenhouse Gas Emissions from the NREL Thermochemical Ethanol Conversion Process. Bioresources 2013, 8:5261-5278.

55. Kylliainen O, Holmbom B: Chemical composition of components in spruce bark waters. Pap Puu-Pap Tim 2004, 86:289-292.

56. Sluiter JB, Ruiz RO, Scarlata CJ, Sluiter AD, Templeton DW: Compositional Analysis of Lignocellulosic Feedstocks. 1. Review and Description of Methods. J Agr Food Chem 2010, 58:9043-9053.

57. Thammasouk K Tandjo D, Penner MH: Influence of extractives on the analysis of herbaceous biomass. J Agr Food Chem 1997, 45:437-443.

58. Chen Y, Stevens MA, Zhu Y, Holmes J, Xu H: Understanding of alkaline pretreatment parameters for corn stover enzymatic saccharification. Biotechnol Biofuels 2013, 6:1-10.

59. Chaturvedi V, Verma P: An overview of key pretreatment processes employed for bioconversion of lignocellulosic biomass into biofuels and value added products. 3 Biotech 2013, 3:415-431.

60. Yu ZY, Jameel H, Chang HM, Park S: The effect of delignification of forest biomass on enzymatic hydrolysis. Bioresource Technol 2011, 102:9083-9089.

61. Mittal A, Katahira R, Himmel ME, Johnson DK: Effects of alkaline or liquid-ammonia treatment on crystalline cellulose: changes in crystalline structure and effects on enzymatic digestibility. Biotechnol Biofuels 2011, 4:41-55.

62. Krassig HA: Methods of activation. In Cellulose. 11th edition. Edited by Krassig HA. Netherlands: Taylor \& Francis; 1993:215-258.

63. Sathitsuksanoh N, Zhu ZG, Wi S, Zhang YHP: Cellulose Solvent-Based Biomass Pretreatment Breaks Highly Ordered Hydrogen Bonds in Cellulose Fibers of Switchgrass. Biotechnol Bioeng 2011, 108:521-529. 
64. Kim SB, Lee SJ, Lee JH, Jung YR, Thapa LP, Kim JS, Um Y, Park C, Kim SW: Pretreatment of rice straw with combined process using dilute sulfuric acid and aqueous ammonia. Biotechnol Biofuels 2013, 6:109-119.

65. Cheng YS, Zheng Y, Yu CW, Dooley TM, Jenkins BM, VanderGheynst JS: Evaluation of High Solids Alkaline Pretreatment of Rice Straw. Appl Biochem Biotech 2010, 162:1768-1784.

66. Miron J, Benghedalia D: Effect of Hydrolyzing and Oxidizing-Agents on the Composition and Degradation of Wheat Straw Monosaccharides. Eur J Appl Microbiol 1982, 15:83-87.

67. Lu FC, Ralph J: The DFRC method for lignin analysis. Part 3. NMR studies. J Wood Chem Technol 1998, 18:219-233.

68. Blumenkr N, Asboehan G: New Method for Quantitative-Determination of Uronic Acids. Anal Biochem 1973, 54:484-489.

69. Park S, Baker JO, Himmel ME, Parilla PA, Johnson DK: Cellulose crystallinity index: measurement techniques and their impact on interpreting cellulase performance. Biotechnol Biofuels 2010, 3:10-19.

70. Overend RP, Chornet E: Fractionation of Lignocellulosics by Steam-Aqueous Pretreatments. Philos TR Soc A 1987, 321:523-536.

71. Chum HL, Johnson DK, Black SK, Overend RP: Pretreatment Catalyst Effects and the Combined Severity Parameter. Appl Biochem Biotech 1990, 24-5:1-14.

72. Sasikumar E, Viruthagiri T: Optimization of Process Conditions Using Response Surface Methodology (RSM) for Ethanol Production from Pretreated Sugarcane Bagasse: Kinetics and Modeling. Bioenerg Res 2008 1:239-247.

doi:10.1186/2043-7129-2-12

Cite this article as: Elumalai et al.: Combined sodium hydroxide and ammonium hydroxide pretreatment of post-biogas digestion dairy manure fiber for cost effective cellulosic bioethanol production. Sustainable Chemical Processes 2014 2:12

\section{Publish with ChemistryCentral and every scientist can read your work free of charge \\ "Open access provides opportunities to our colleagues in other parts of the globe, by allowing anyone to view the content free of charge." \\ W. Jeffery Hurst, The Hershey Company. \\ - available free of charge to the entire scientific community \\ - peer reviewed and published immediately upon acceptance \\ - cited in PubMed and archived on PubMed Central \\ - yours - you keep the copyright \\ Submit your manuscript here: \\ http://www.chemistrycentral.com/manuscript/<smiles>c1ccccc1</smiles> \\ Chemistry Central}

